\title{
Effect of Net Cash Flows on Investors' Decisions on Companies Listed in Amman Stock Exchange during the Period of 2001-2017: A Case Study on Industry and Service Sectors
}

\author{
Ateyah Mohammad Alawneh \\ Faculty of Business, Tafilah Technical University, Jordan
}

Copyright@2019 by authors, all rights reserved. Authors agree that this article remains permanently open access under the terms of the Creative Commons Attribution License 4.0 International License

\begin{abstract}
This study aims to estimate the impact of net cash flows on investors' decisions on industrial and service companies listed in the Amman Stock Exchange during the period of 2001-2017. The study is based on data from the accumulated annual reports of the previously mentioned industrial and service companies. The study tests autocorrelation by using the Breusch-Godfrey serial correlation Lagrange multiplier test, and the analysis shows no autocorrelation between the variables of the study. Moreover, the study tests the stability of the variance by using the autoregressive conditional heteroskedasticity test, and the results show the absence of a variation problem among the study variables and models. Thus, they do not suffer from measurement problems. Hypotheses testing through the measurement analysis of the industrial sector show a negative impact of net investment cash flow on investors' decisions. However, net financing cash flow has a positive effect on investors' decisions, while net operation cash flow has no statistically significant effect on investors' decisions. The analysis of the service sector reveals a statistically significant negative effect of net operation cash flow on investors' decisions, whereas net financing cash flow has no effect on investors' decisions. The study concludes with a set of recommendations, the most important of which is the need for companies to pay attention to net investment cash flows to buy companies with fixed assets and to use traditional financing alternatives such as murabaha, musharaka, and Islamic sukuk hedging instruments.
\end{abstract}

Keywords Investor's Decision, Investment Cash Flows, 0peration Cash Flows, Financing Cash Flows, Industry Sector, Services Sector

\section{Introduction}

Companies should set and review cash flow statements in detail and extract information on net cash flows for prospective use on important decisions, such as planning investment opportunities and investor decision-making processes as well as promoting such processes.

The decision to invest is an important process because it is serious, irreversible, risky, and requires long-term guarantees. Investors need to obtain and understand cash flows. Therefore, cash flows prepared by the management should be analyzed based on assets before an investment decision is made (Patrick, Tavershima, and Eje, 2017). Every company possesses internal and external cash flows in which internal cash flows are greater than cash outflows, thereby reflecting a net positive cash flow, and vice versa. Corporate cash flows are divided into three types of net cash flows, namely, net investment cash flow, net Operation cash flow, and net financing flow. Net investment cash flow is derived from the sale of fixed assets minus the purchase of fixed assets. Net operation cash flow represents inflows from ordinary activities minus the flows paid to normal activities. Net financing cash flow is money earned from financing operations minus money paid to financing operations.

Results of net Cash Flows may be negative or positive, which means that if the cash inflows of a company are greater than its outflows, then the result would be positive, and vice versa. This study is based on the three cash flows and their role in influencing investors' decisions on companies in industrial and service sectors listed in the Amman Stock Exchange (ASE). Investors' decisions on such companies depend on several factors; however, the present study focuses only on cash flows and their role in influencing investors' decisions. This subject is rarely discussed in the literature on finance and economics. 
Therefore, the present study estimates and analyzes of the impact of net cash flows on investors' decisions. A case study on industrial and service companies listed in the ASE is conducted to determine the most important impact on the decision of investors. The service and industrial sectors are selected for the study because they are among the largest in the Jordanian economy. Moreover, the selection of two major sectors in the Jordanian market can enable the results of the study to be compared and generalized. The study will focus mainly on theoretical concepts in the Introduction, followed by the presentation of the research problem, the hypotheses, the importance of the research objectives, the study variables, the measurement models used in the study, and the measurement analysis. The study is divided into two models. The first model presents the effects of net cash flows in the industrial sector, and the second model discusses the impacts of net cash flows in the service sector. Moreover, the study will consider other tests for the model, including autocorrelation and the instability of the variance. Finally, the hypotheses are tested and interpreted, and the results and recommendations are presented.

\subsection{Problems of the Study}

The problem of the study embodies the situation of the industrial and service sectors in which investors have an interest in cash flows to make investment decisions on companies listed in the ASE as well as the potential relationship between these decisions and the three types of cash flows (investment, operation, and finance). The research problem can be studied by asking the following questions.

1. What is the impact of net investment cash flow on the decision of investors on companies in the industrial sector listed in the ASE?

2. What is the effect of net operation cash flow on the decision of investors on companies in the industrial sector listed in the ASE?

3. What is the effect of net financing cash flows on the decision of investors on companies in the industrial sector listed in the ASE?

4. What is the impact of net investment cash flows on the decision of investors on companies in the service sector listed in the ASE?

5. What is the effect of net operation cash flows on the decision of investors on companies in the service sector listed in the ASE?

6. What is the effect of net financing cash flows on the decision of investors on companies in the service sector listed in the ASE?

\subsection{Objectives}

The aim of the study is to estimate the impact of cash flows on investors' decisions on companies in industrial and service sectors listed in the ASE. It also aims to clarify the concept of cash flows and their development during the study period with regard to companies in the industrial and service sectors listed in the ASE. Moreover, it aims to shed light on the concept of cash flows, namely, investment, operation, and financing.

Furthermore, the study evaluates the indicators of investors' decisions and presents results and recommendations that can assist decision makers in making investment decision.

\subsection{Importance of the Study}

This study investigates companies listed in the Amman Financial Market, especially those in the industrial and service sectors, to determine the role of cash flows on investment decisions on these companies. Moreover, the study promotes investment decisions among companies and considers the role of cash flows in influencing investors aiming to invest in companies listed in the ASE. Accordingly, the study can help improve investment management during the investment process.

\subsection{Methodology}

The descriptive approach and inference are used in the inductive and deductive methods. The study relies on references, existing studies, and periodicals and uses a historical approach and quantitative analysis for the measurements. In addition, the study uses secondary sources as its basis, including statistical publications issued by the ASE, to obtain cash flow data and other data related to investors' decisions on companies in industrial and service sectors listed in the ASE.

\subsection{Variables of the Study}

\section{Independent Variables}

NCFII: the value of net cash flow investment in the industry during the years of study

NCFOI: The value of net cash flow operation in the industry during the years of study

NCFFI: The value of net cash flow financing in the industry during the years of study

NCFIS: The value of net cash flow investment in the service sector during the years of study

NCFOS: The value of net cash flow operation in the service sector during the years of study.

NCFFS: The value of net cash flow financing in the service sector during the years of study

\section{Dependent Variables}

DMI: Investor Decision in the Industry Sector Index

DMS: Investor decision in the service sector Index

\subsection{Measurement Models}

The multi-linear regression method and the (E-views) program will be used to study the effect of independent 
variables on the main sectors indices of listed companies in Amman Stock Exchange as follows

Model 1: Impact of net cash flows on investor decision in industry sector

DMI: f (NCFII, NCFOI, NCFFI)

Whereas:

DMI: Investor Decision in the Industry Sector Index

NCFII the value of net cash flow investment in the industry during the years of study

NCFOI: The value of net cash flow operation in the industry during the years of study

NCFFI: The value of net cash flow financing in the industry during the years of study

Model 2: Impact of net cash flows on investor decision in the service sector

DMS f (NCFIS, NCFOS, NCFFS)

Whereas:

DMS: Investor decision in the service sector Index

NCFIS: The value of net cash flow investment in the service sector during the years of study

NCFOS: The value of net cash flow operation in the service sector during the years of study.

NCFFS: The value of net cash flow financing in the service sector during the years of study

\section{Related Literature and Theoretical Framework}

\subsection{Related Literature}

Numerous studies on cash flows exist, and their effects on the financial variables of business organizations and on investors' decisions are described in this section.

Call (2007) aimed to clarify the role of analysts' expectations on cash flows in investors' pricing and managers' reporting of earnings and found that pricing stock prices for investors will result in the low weights of cash flows. However, the study showed that expected cash flows affects profits and the pricing of company shares. Gitari (2014) determined the impact of investment cash flows on the fixed assets of listed companies in the Nairobi Stock Exchange

The study used data from the Nairobi Stock Exchange and the analysis showed the positive impact of cash flows on investment, especially among small businesses in the agriculture, manufacturing, construction, and automotive sectors. The study concluded with a set of recommendations, particularly that concerned authorities should develop policies aimed to accelerate the development of financial systems. In addition, measures should be taken to ensure that risk is maintained at minimum levels.

Nobanee and Abraham (2017) analyzed the impact of cash flows, property equity, and agency costs on the profitability of insurance companies listed in the Saudi
Stock Exchange. The analysis showed that capital has no significant impact on agency costs. Moreover, it was found that cash flows have no impact on agency costs, while agency costs have no significant impact on the profitability of a company. However, the study failed to provide evidence supporting agency theory among the insurance companies listed in the Saudi stock market.

Fodio and Onah (2013) estimated the impact of the net investment cash flow levels of industrial companies listed in Nigeria. The study investigated whether investment is sensitive to cash flow generated internally. Similarly, the study analyzed the investment levels of 16 companies registered during the period of 2004-2008 by using the ordinary least squares regression method. The analysis showed a positive correlation between investment and cash flows and that the size of a company has a significant negative impact on the relationship between cash flows and investment. In addition, industrial classification is observed to have an uneven effect on the relationship between investment and cash flows. Furthermore, the study presented a positive correlation between cash flows and investment in chemical companies and in those that sold paints and building materials. However, a negative correlation is observed between cash flows and investment in food, beverage, and tobacco companies. The study concluded that the classification of an industry determines the relationship between cash flows and investment. Melander, Sandström, and von Schedv (2017) examined the impact of cash flows on investment by relying on accounting data and testing balance sheet theory. The authors' analysis showed a positive effect of cash flows on investment, especially for companies that are financially restricted.

Upneja and Sharma (2009) clarified the relationship between investments in fixed assets and free cash flows for restaurant companies in the United States. The results of the study indicated that investments in small companies (with high financial constraints) have a relatively weak sensitivity to cash flows, whereas investments in large firms have a relatively strong sensitivity to cash flows.

Al Zararee and Al-Azzawi (2014) examined the relationship between cash flows and market value in the pharmaceutical sector in Jordan, and the analysis showed a positive relationship between cash flows and market value. Moreover, the analysis demonstrated that the market value of the companies is significantly affected by valuation through the use of cash flows.

Khanji and Siam (2015) investigated the effect of cash flows on the share price of Jordanian commercial banks listed in the ASE, specifically, operation, financing, and investment cash flows.

The study sample consisted of 12 Jordanian banks and used annual reports to obtain data. The statistical analysis of the study demonstrated the limited impact of operational investment and financing cash flows on the market value of the Jordanian shares. One of the main recommendations of 
the study was to consider cash flows when conducting stock price assessments.

Syed Mohammad Khaled Rahman, Md \& Tahidur Rahman (2017) explained the impact of leverage on the cash flows of local and multinational listed companies during the period of 1996-2015. A total of 14 companies were selected, 7 of which were multinational and the remaining 7 were local companies. The measurement analysis concluded that leverage growth has a significant impact on cash flows.

Khan, Kaleem, and Nazir (2012) analyzed the leverage effect on an agency's free cash flow costs in the industry sector in Pakistan. The study was based on the ratio of debt to capital and long-term debt to equity. The study sample consisted of 54 industrial companies for the period of 2006-2010 and used corporate data from the Karachi 100 Index. The results showed that a company's financial leverage plays an important role in reducing an agency's cost of free cash flows by reducing free cash flows under the control of a manager. Furthermore, the study demonstrated that the result is consistent with theory of free cash flows.

Liman and Mohammed (2018) expounded on the impact of operational cash flows and financial performance on companies listed in the Nigeria Stock Exchange for the period of 2005-2014. The study used descriptive statistics, correlation analysis, and linear regression techniques. The results presented a positive but not statistically significant effect on the relationship between cash flows and return on assets. However, the effect on the relationship between operational flows and return on equity is positive.

Lewellen and Lewellen (2016) described the sensitivity of cash flows to investment decisions in listed American companies for the period of 1971-2002. The analysis presented the importance of cash flows in influencing investors' decisions.

Patrick, Tavershima, and Eje, (2017) conducted empirical investigations on the impact of financial information on the investment decision of shareholders in banks in Nigeria. The study relied on published data from the annual reports of five selected banks in Nigeria for the period of 2009-2015. The results showed current and future investors are interested in financial information related to the distribution of profits paid to shareholder when making decisions to invest in the shares of Nigerian banks.

Afifah and Ghneim(2000) studied the sensitivity of accounting disclosures through financial ratios in influencing investment decisions on Jordanian industrial joint stock companies. The study highlighted the importance of accounting disclosures through financial ratios in the accounting statements of industrial companies to interpret investment decisions based on the market price of the share. The study described the relationship between accounting statements expressed as financial ratios (statement of income, statement of financial position, statement of cash flows, and statement of changes in equity) and investment decisions (equity turnover). Moreover, the market price of the sample companies was considered. The study concluded with a set of recommendations, including the necessity to increase the level of investors and the factors that increase the importance of accounting disclosures when making investment decisions

\subsection{Study Features}

The present study differs from previous studies in the following aspects.

First, to the best of the knowledge of the researcher, this research is one of the few studies on Arab society and the first in Jordan that is concerned with estimating the impact of cash flows on the decisions of the investor on companies in the industrial and service sectors listed in the Amman Financial Market.

Second, to the best of the knowledge of the researcher, this research is one of the few studies that is concerned with studying the effect of cash flows on investors' decisions on companies in the industrial and service sectors at the global level. Most previous studies have focused on the impact of cash flows on investment and profitability; however, the present study determines the impact of cash flows, investment, 0peration, and financing on investor decisions. Furthermore, this research is the first to use the multiple linear regression method, namely, E-views, to study the effect of the variables of net cash flows (operational, investment, and financing) on the dependent variable.

\subsection{Theoretical Framework}

The concept of cash flow is explained as well as its development during the study period.

\subsection{Concept of Cash Flow}

This study focuses on net investment cash flow, net operation cash flow and net financing cash flow, which are defined below.

- Investment cash flow: may be positive if company money is invested to generate cash but negative if funds are not used fully in new cash-generating investments (Florentina-Simona, 2010,). However, new investments are classified as capital expenditures or net capital expenditures, which are the cash flows from the sale of fixed assets minus cash flows from the purchase of fixed assets (Ross, Westerfield, and Jordan, 2010).

- Operation cash flow: This cash flow is cash generated from normal firm business activity. Operation cash flow is calculated as the earnings before interests and taxes plus depreciation minus taxes (Ross, Westerfield, and Jordan, 2010). Cash 
flow from 0peration activities determines the future role of a company and the development of the institution because it indicates that activities can lead to the generation of cash for loan payments, financing, maintenance, and profit distribution (Florentina-Simona, 2010,)

- Financing cash flow: Cash flows arising from changes in an entity's capital and financing structure are positive when a company obtains external financing sources to supplement the results from operations. However, cash flows from financing activities are negative owing to large payments, such as loan and interest payments and financial rent obligations (Florentina-Simona, 2010).

\subsection{Development of Net Cash Flows in Industry and Service Sectors during the Study Period}

\subsubsection{Development of Net Cash Flows in the Industry} Sector

\subsubsection{Development of Net Investment Cash Flows}

Figure 1 presents the development of net investment cash flows during the study period, which was negative in most years until the end of the study. This finding means that the outflows from this sector are greater than the inflows; thus, net cash flows are negative. This result indicates that funds are not fully used in new investments that generate cash. This situation has a negative impact on the decision of investors, especially in the industrial sector, which depends heavily on cash flows from cash-generating investment activities.

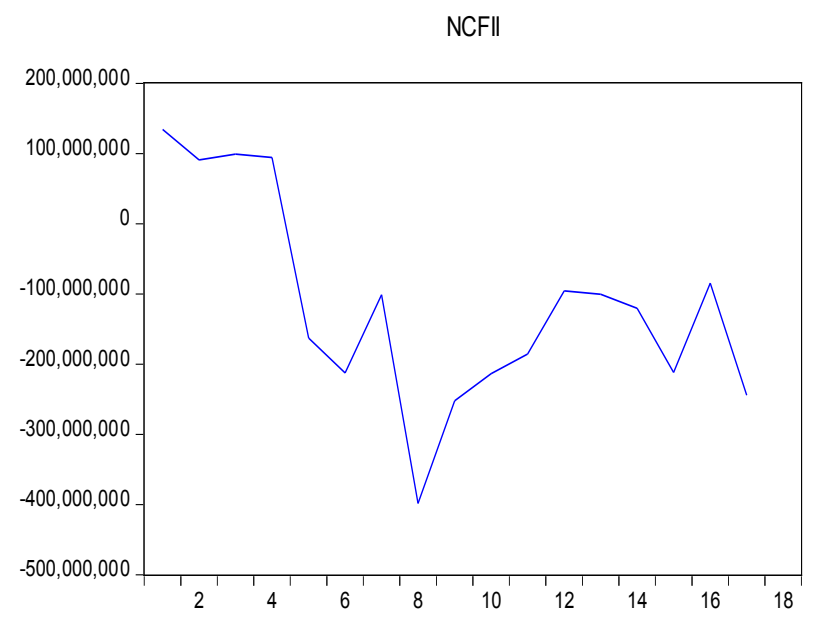

Source: E- views program based on appendix (1).

Figure 1. The development of net investment cash flows during the years of study

The descriptive analysis of Annex 8 shows that the highest value of net investment cash flows in the industrial sector is approximately $(1.34 \mathrm{E}+08)$ million Jordanian dollars, and the lowest value is $(-3.98 \mathrm{E}+08)$ million Jordanian dollars, with an average of $(-1.16 \mathrm{E}+08)$ million
Jordanian dollars and a measurement deviation of $(1.47 \mathrm{E}+08)$ during the study period.

\subsubsection{Development of Net operation Cash Flows}

Figure 2 indicates the evolution of net operation cash flows during the study period, which was positive. This finding means that cash inflows into the sector are greater than outflows from the sector. However, net operation cash flows include gross profit including taxes, interests, and depreciation, which may not interest investors when making investment decisions.

The descriptive analysis of Annex 8 shows that the highest value of net 0peration cash flows in the industrial sector is approximately $(5.73 \mathrm{E}+08)$ million Jordanian dollars, and the lowest value is $(1.24 \mathrm{E}+08)$ million Jordanian dollars, with an average of $(-5.73 \mathrm{E}+08)$ million Jordanian dollars and a measurement deviation of $(1.24 \mathrm{E}+08)$ during the study period.

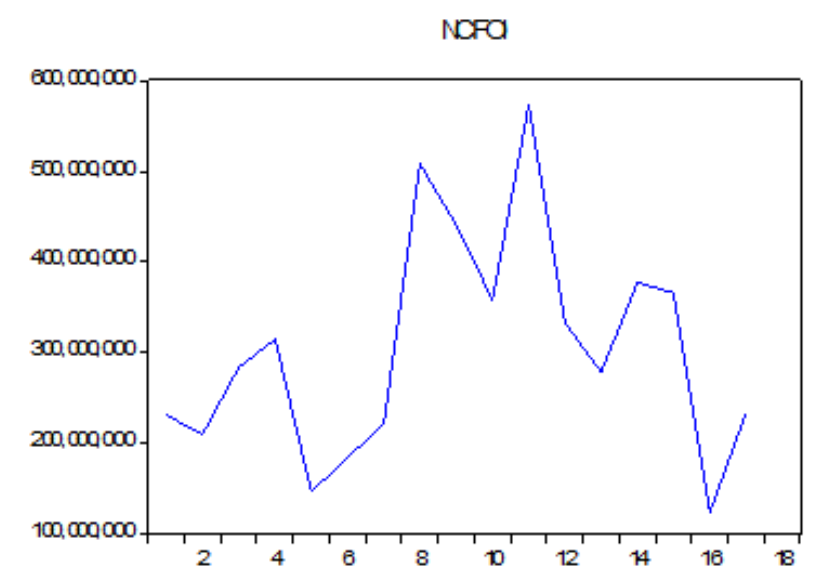

Source: E- views program based on appendix (1).

Figure 2. The development of net 0peration cash flows during the years of study

\subsubsection{Development of Net Financing Cash Flows}

Figure 3 shows that net cash flows were positive during the first year of the study period until 2004. Then, net cash flows became negative until the end of the study in 2017. This finding means that cash outflows from the sector are greater than inflows into the sector, thereby indicating that companies in the industrial sector are distributed to large amounts to shareholders. This distribution leads to a high share price in the market, thereby reflecting the efficiency of the management in the sector to obtain profits. Such profits can affect investment decisions in this sector owing to investors' beliefs that distribution can be obtained from investment.

The descriptive analysis of Annex 8 shows that the highest value of net financing cash flows in the industrial sector is approximately $(2.24 \mathrm{E}+08)$ million Jordanian dollars, and the lowest value is $(-3.34 \mathrm{E}+08)$ million Jordanian dollars, with an average of (-61915314) million Jordanian dollars and a measurement deviation of $(1.78 \mathrm{E}+08)$ during the study period. 


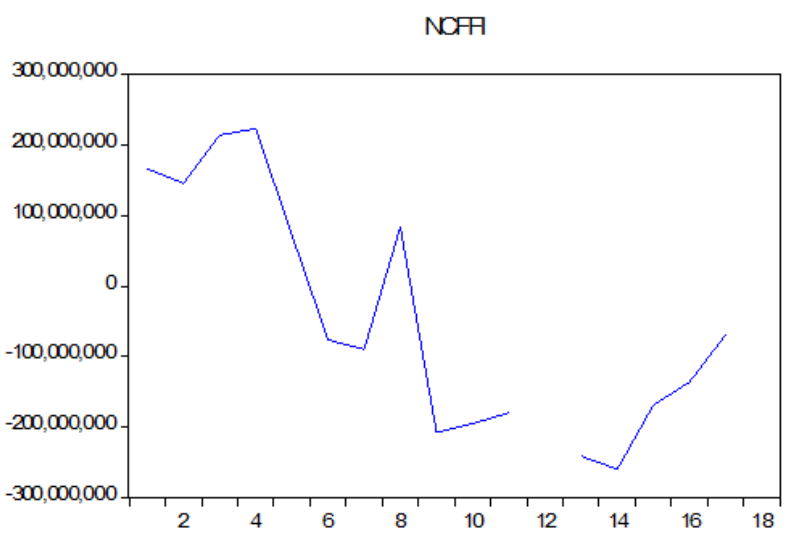

Source: E- views program based on appendix (1).

Figure 3. The Development of net finance cash flow during the years of study

\subsubsection{Development of Net Cash Flows in the Service Sector}

\subsubsection{Development of Net Investment Cash Flows}

Figure 4 indicates the development of net investment cash flows during the study period, which was negative in most years until 2015, 2016, and 2017, when it became positive. This finding means that outflows from the sector are greater than inflows into the sector, which indicates that the participation of companies in the industrial sector is because the service sector is interested in acquiring assets, machinery and equipment, and modern technology. These acquisitions are motivated by the high competition between the two sectors as well as growth, expansion, and development, which promote investors' decisions, especially in the service sector. The service sector depends on the provision of fast and accurate services appropriate to the needs of large investments to be spent on the competition between these sectors in Jordan.

NCFIS

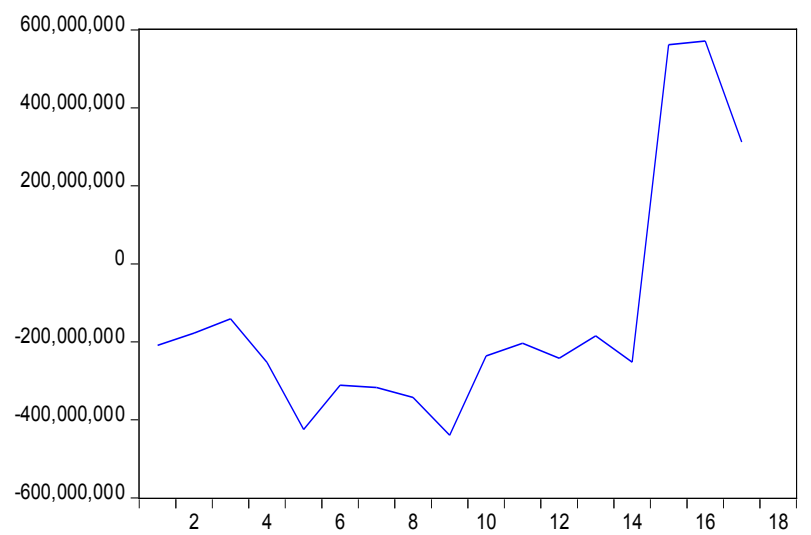

Source: E- views program based on appendix (1).

Figure 4. The development of net investment cash flows during the years

The descriptive analysis of Annex 8 shows that the highest value of net investment cash flows in the service sector is approximately $(5.7+08)$ million Jordanian dinar, and the lowest value is $(-4.39 \mathrm{E}+08)$ million Jordanian dinar, with an average of $(1.35 \mathrm{E}+08)$ million Jordanian dollars and a measurement deviation of $(3.10 \mathrm{E}+08)$ during the study period.

\subsubsection{Development of Net Operation Cash Flows}

Figure 5 indicates the development of net 0peration cash flows during the study period, which was positive. This finding means that cash inflows into the sector are greater than outflows from the sector. However, Operation cash flows include taxes, interests, and consumption. The large volume reflects large taxes and may adversely affect investment decisions because the service sector in Jordan imposes high tax rates.

The descriptive analysis of Annex 8 shows that the highest value of net 0peration cash flows in the service sector is approximately $(1.92 \mathrm{E}+09)$ million Jordanian dinar, and the lowest value is $(-94703534)$ million Jordanian dinar, with an average of $(-4.67 \mathrm{E}+08)$ million Jordanian dinar and a measurement deviation of $(5.53 \mathrm{E}+08)$ during the study period.

\section{NCFOS}

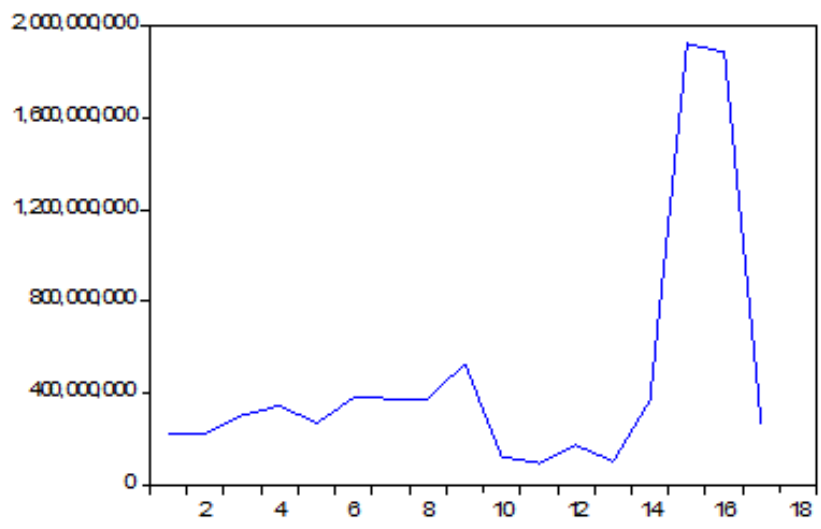

Source: E- views program based on appendix (1).

Figure 5. The development of net 0 peration cash flows during the years of study

\subsubsection{Development of Net Financing Cash Flows}

Figure 6 demonstrates the development of net financing cash flows during the study period, which fluctuated between negative and positive but was negative in most years. However, net financing cash flows became positive during the end of the study period in 2015, 2016, and 2017.

The instability of the fluctuation of the financing flows between negative and positive may be underestimated by investors.

The descriptive analysis of Annex (8) shows that the highest value of net financing cash flows in the service sector is approximately $(9.17 \mathrm{E}+08)$ million Jordanian dinar, and the lowest value is $(-2.78 \mathrm{E}+08)$ million Jordanian dinar, with an average of (65003082) Jordanian dinar and a measurement deviation of $(2.54 \mathrm{E}+08)$ during the study period. 
NCFFS

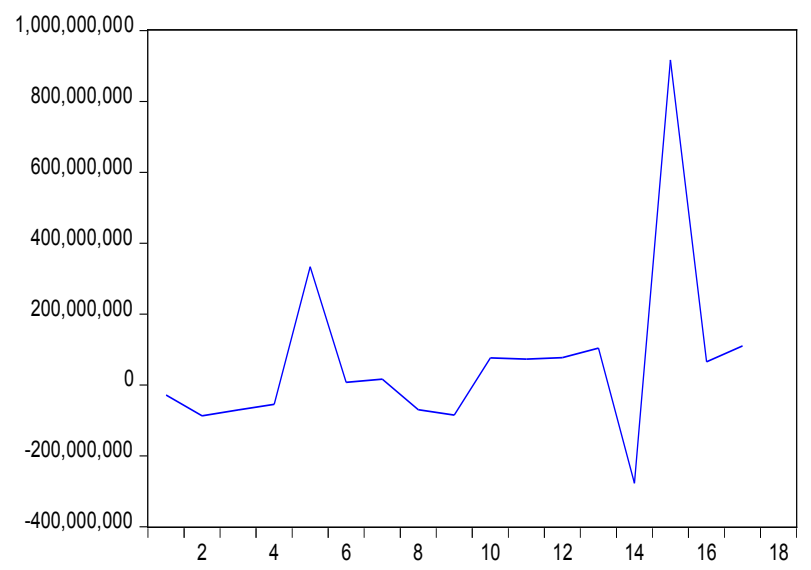

Source: E- views program based on appendix (1).

Figure 6. The Development of net finance cash flow during the years of study

\subsubsection{Investment Decision}

Making decisions means the selection of options from available alternatives to achieve a specific goal. Stoner (2000) defined decision as, the process of identification and selection of workflow limits. According to Bode, Kane, and Marcus (2001), investment is a commitment to current or other resources in anticipation of future benefits. Pandey (2005) identified investment decisions as the effective allocation of capital, including investing funds in long-term assets. Such decisions are of considerable importance to company size because they influence growth, profitability, and risks (Patrick, Tavershima, and Eje, 2017).

Investment decision is referred to by the ratio and expressed (share turnover) by the number of shares traded/subscribed at the end of a period, (Abu Afifah \& Ghneim, 2000) and (Patrick and Eje, 2017) demonstrated the concept of investors' decisions through the number of shareholders. The considerable number of shares traded during the study period increased investment decisions because it reflected the increased activity of investors and the subsequent increase in investment. This situation depends on numerous factors, including investment, operation, and financing cash flows, as indicated by previous studies. For example, Gitari (2014) and Fodio and Onah (2013) indicated a positive correlation between cash flows and investment because cash flows lead to increased investment, which supports and strengthens investment decisions of investors.

Figure 7 presents the development of investment decisions in the industrial sector (the number of shares traded/ subscribed), which increased during the beginning of the study period and continued to rise until it reached the highest value in 2008. This finding is attributed to the increase in the number of shares traded to the number of shares subscribed, which reflects the increase of investment activities and investments in industrial companies. However, decreased as shown in the mechanism in the chart above. The result of the decline in the number of shares traded is expressed by the decline of investments in industrial companies. Consequently, continued to decline until the end of the study period in 2017. The development of investment decisions in the industrial and service sectors during the study period is presented in Figures 7 and 8.

The descriptive analysis of Annex (8) shows that the highest value of investment decisions in the industrial sector is approximately (1.544370), and the lowest value is (0.404076), with an average of (0.569176) and a measurement deviation of $(0.374480)$ during the study period.

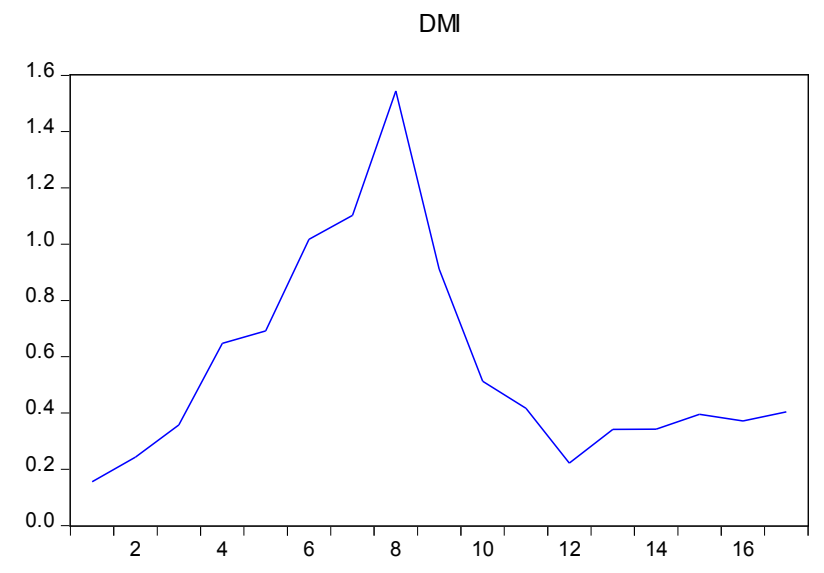

Source: E- views program based on appendix (1).

Figure 7. The development of the investment decision during years of the study in the industrial sector

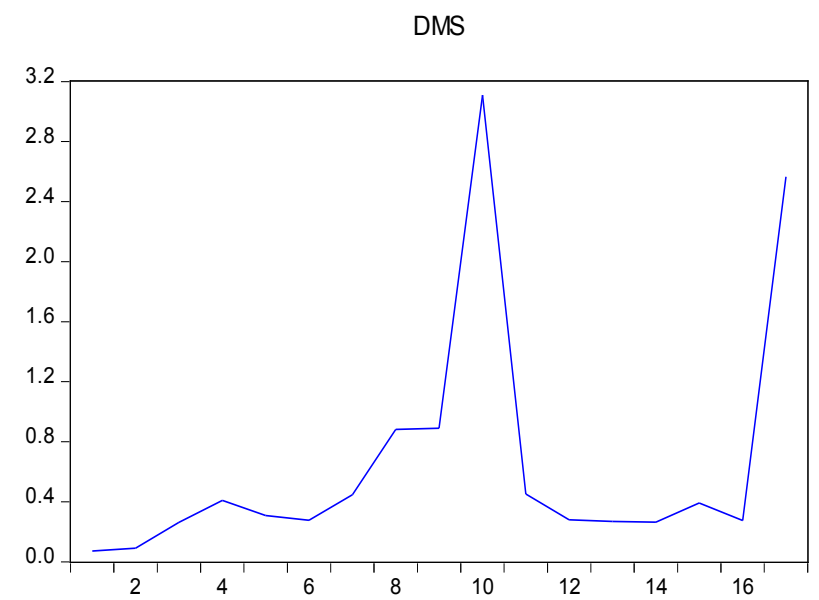

Source: E- views program based on appendix (1).

Figure 8. The development of the investment decision during years of the study in the services sector

Figure 8 indicates that investment decisions in the service sector increased in the beginning of the study period and continued to rise until they reached the highest value in 2010. This finding is attributed to the increase in the number of shares traded to shares subscribed as well as to the increase in the number of shares subscribed. The number of subscribed shares reflects the increase of 
investment activities and investments in service companies, which have decreased. Moreover, the mechanism described in the chart above presents the result of the decline in the number of shares traded, which is expressed by the decline of investments in services companies, which continued to decline until the beginning of 2017 but rose by the end of the same year.

The descriptive analysis of Annex 8 shows that the highest value of investment decisions in the service sector is approximately (3.109633), and the lowest value is $(0.071455)$, with an average of (0.661366)and a measurement deviation of (0.853558) during the study period.

\section{Measurement Analysis}

The present study is divided into two models.

\subsection{Model 1: The Impact of Net Cash Flows on Investors' Decisions in the Industry Sector}

The multiple regression method is conducted by using the E-views program. The model is estimated, and the results are shown as follows.

Were shown as follows

Table 1. Dependent Variable: DMI

\begin{tabular}{|c|c|c|c|}
\hline Prob. & t-Statistic & Coefficient & Variable \\
\hline 0.0013 & -4.076938 & $-2.26 \mathrm{E}-09$ & NCFII \\
\hline 0.9941 & -0.007520 & $-4.44 \mathrm{E}-12$ & NCFOI \\
\hline 0.0146 & 2.816648 & $1.21 \mathrm{E}-09$ & NCFFI \\
\hline 0.0482 & 2.180079 & 0.384019 & C \\
\hline
\end{tabular}

Source: E- views program based on appendix (1).

Table 1 shows that all the variables are statistically significant except for the operational flow variable (NCFOI), which is statistically insignificant. Thus, the model is recalculated by deleting statistically significant variables

The equation can be written as follows:

$$
\mathrm{DMI}=0.38-2.28 \mathrm{E}-09 \text { (NCFII) +1.21E-09 (NCFOI) }
$$

The adjusted R-squared value of the model is $54.16 \%$. This finding means that changes in the independent variables $(54.16 \%)$ are interpreted together with the changes in the dependent variable. The value of the
F-statistics is 10.45 , with a potential of 001669 .

Table 2. Dependent Variable: DMI

\begin{tabular}{|c|c|c|c|}
\hline Prob. & t-Statistic & Coefficient & Variable \\
\hline 0.0005 & -4.516203 & $-2.26 \mathrm{E}-09$ & NCFII \\
\hline 0.0110 & 2.929707 & $1.21 \mathrm{E}-09$ & NCFFI \\
\hline 0.0003 & 4.835974 & 0.382847 & $\mathrm{C}$ \\
\hline
\end{tabular}

Source: E- views program based on appendix (1).

$59.8 \%: \mathrm{R}$-squared

Adjusted R-squared: $54.16 \%$

F-statistic: 10.45

Prob (F-statistic): 0.001669

Durbin-Watson stat: 1.23

Autocorrelation is tested by the E-views program using the Breusch-Godfrey serial correlation Lagrange multiplier (LM) test to check the problem of autocorrelation in the model. Table 3 and Appendix 3 show that the Chi-square probability at lags (1) and (2) are greater than $5 \%$, which indicates the absence of the autocorrelation problem in the model.

Table 3. Tested (Autocorrelation) Using a test (Breusch-Godfrey Serial Correlation LM Test)

\begin{tabular}{|c|c|}
\hline Prob. Chi-Square(1) 0.0879 & $\operatorname{lag}(1)$ \\
\hline 0.1499 Prob. Chi-Square(2) & $\operatorname{lag}(2)$ \\
\hline
\end{tabular}

Source: E- views program based on appendix (1).

Variance is tested by the E-views Program using the autoregressive conditional heteroskedasticity test (ARCH) to check the problem of variance in the model. Table 4 and Appendix 4 demonstrate that the Chi-square probability at lags (1) and (2) are greater than 5\%, which indicates the absence of variance instability in the model.

Table 4. Tested (variance) through using a test (Heteroskedasticity Test: ARCH)

\begin{tabular}{|l|r|}
\hline 0.9320 Prob. Chi-Square(1) & $\operatorname{lag}(1)$ \\
\hline 0.3494 Prob. Chi-Square(2) & $\operatorname{lag}(2)$ \\
\hline
\end{tabular}

Source: E- views program based on appendix (1).

Several measurement tests, namely, the stability and validity tests, are conducted to verify the model. Figure 8 shows that the ratio of the bias proportion equals zero, and the dispersion coefficient (percentage differences) or the variance proportion is less than $12 \%$. Moreover, the value of the covariance ratio is $87.25 \%$, which means that the error in the model is random. 

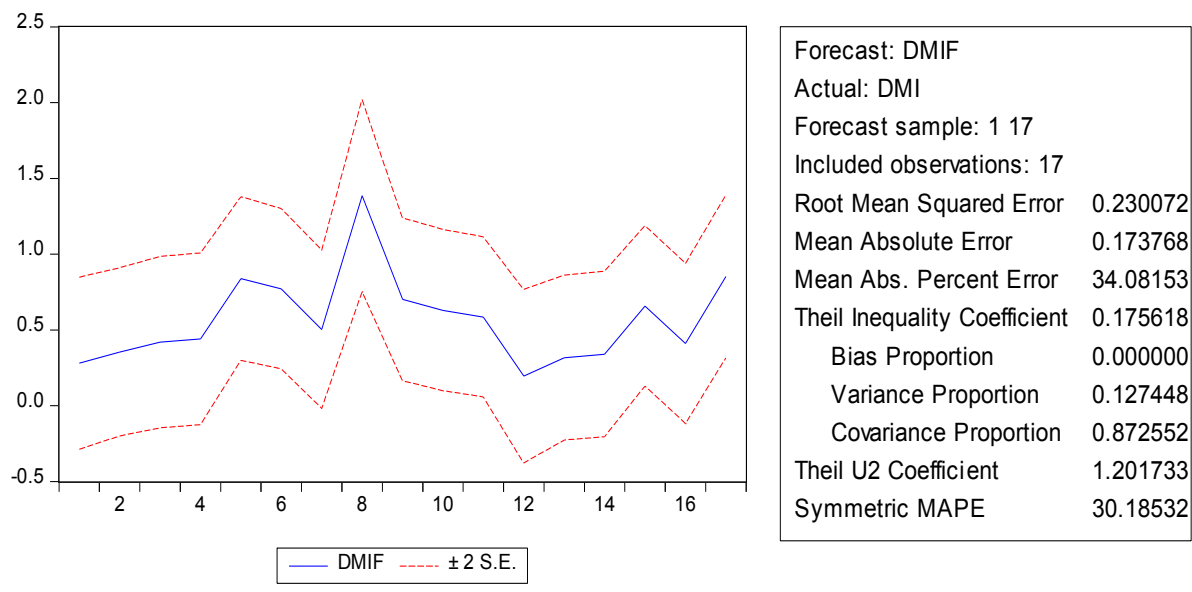

Source: E- views program based on appendix (1).

Figure 9. Tests to verify (the stability test) and validity (validity test) of the model

\subsection{Model II: The Impact of Net Cash Flows on Investors' Decisions in the Service Sector}

The multiple linear regression method is conducted by using the E-views program. The model and the results are estimated as follows.

The model is estimated, as shown in Appendix 5. None of the variables are statistically significant. Therefore, a delay is conducted for all the independent variables to improve the model, as shown in Table 5.

Table 5. Dependent Variable: DMS

\begin{tabular}{|c|c|c|c|}
\hline Prob. & t-Statistic & Coefficient & Variable \\
\hline 0.0260 & 2.539347 & $2.64 \mathrm{E}-09$ & D(NCFIS) \\
\hline 0.0003 & -4.928492 & $-1.76 \mathrm{E}-09$ & D(NCFOS) \\
\hline 0.3900 & 0.891840 & $3.84 \mathrm{E}-10$ & D(NCFFS) \\
\hline 0.0009 & 4.391038 & 0.613327 & $C$ \\
\hline
\end{tabular}

Source: E- views program based on appendix (1).

Table 5 shows that all variables are statistically significant except for the net financing cash flow variable (DNCFFS), which is not statistically significant. Thus, the model is recalculated by deleting variables with no statistical significance, as shown in Table 6.

Table 6. Dependent Variable: DMS

\begin{tabular}{|c|c|c|c|}
\hline Prob. & t-Statistic & Coefficient & Variable \\
\hline 0.0042 & 3.467552 & $3.11 \mathrm{E}-09$ & D(NCFIS) \\
\hline 0.0002 & -5.048042 & $-1.78 \mathrm{E}-09$ & D(NCFOS) \\
\hline 0.0008 & 4.360914 & 0.601642 & $\mathrm{C}$ \\
\hline
\end{tabular}

Source: E- views program based on appendix (1).

R-squared: $66 \%$

Adjusted R-squared: $61.25 \%$

F-statistic: 12.85

Prob(F-statistic): 0.000830

Durbin-Watson stat: 1.39

The equation can be written as follows

\section{$\mathrm{DMS}=0.603 .11 \mathrm{E}-09+1.21 \mathrm{E}-09 \mathrm{D}(\mathrm{NCFIS})$ - 1.78E-09 D(NCFOS)}

The adjusted R-squared value of the model is $61.25 \%$. This means that changes in the independent variables $(61.25 \%)$ are interpreted together with the changes in the dependent variable. The value of the F-statistics is 12.85 , with a potential of 0.000830 .

Autocorrelation is tested by the E-views Program using the Breusch-Godfrey serial correlation LM test to check the problem of autocorrelation in the model. Table 7 and Appendix 6 show that the Chi-square probability at lags (1) and (2) are greater than $5 \%$, which indicates the absence of the autocorrelation problem in the model.

Table 7. Tested (Autocorrelation) Using a test (Breusch-Godfrey Serial Correlation LM Test)

\begin{tabular}{|l|r|}
\hline Prob. Chi-Square(1) 0.2741 & $\operatorname{lag}(1)$ \\
\hline 0.3442 Prob. Chi-Square(2) & $\operatorname{lag}(2)$ \\
\hline
\end{tabular}

Source: E- views program based on appendix (1).

Variance is tested by the E-views program using the ARCH test. Table 8 and Appendix 7 show that the Chi-square probability at lags (1) and (2) are greater than $5 \%$, which indicates the absence of variance instability in the model.

Table 8. Tested (variance) through using a test (Heteroskedasticity Test: $\mathrm{ARCH})$

\begin{tabular}{|l|l|}
\hline Prob. Chi-Square(1) 0.3433 & $\operatorname{lag}(1)$ \\
\hline 0.2850 Prob. Chi-Square(2) & $\operatorname{lag}(2)$ \\
\hline
\end{tabular}

Source: E- views program based on appendix (1).

Measurement tests, namely, stability and validity tests, are conducted to verify the model. Figure 10 demonstrates that the ratio of the bias proportion equals zero and the dispersion coefficient (percentage differences) or the variance proportion is $10.2 \%$. Moreover, the value of the covariance ratio is $89.8 \%$, which means that the error in the model is random. 


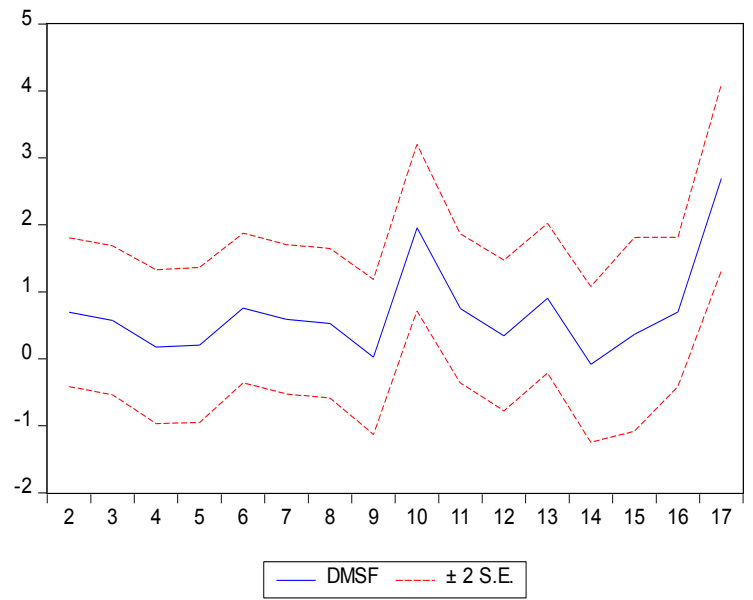

\begin{tabular}{|c|c|}
\hline \\
\hline \multicolumn{2}{|l|}{$\begin{array}{l}\text { Forecast: DMSF } \\
\text { Actual: DMS }\end{array}$} \\
\hline \multicolumn{2}{|l|}{ Forecast sample: 117} \\
\hline \multicolumn{2}{|l|}{ Adjusted sample: 217} \\
\hline \multicolumn{2}{|l|}{ Included observations: 16} \\
\hline Root Mean Squared Error & 0.486689 \\
\hline Mean Absolute Error & 0.385444 \\
\hline Mean Abs. Percent Error & 117.2152 \\
\hline Theil Inequality Coefficient & 0.235110 \\
\hline Bias Proportion & 0.000000 \\
\hline Variance Proportion & 0.101925 \\
\hline Covariance Proportion & 0.898075 \\
\hline Theil U2 Coefficient & 0.568928 \\
\hline Symmetric MAPE & 76.91702 \\
\hline
\end{tabular}

Source: E- views program based on appendix (1).

Figure 10. Tests to verify (the stability test) and validity (validity test) of the model

\section{Hypotheses Test}

The hypotheses are tested based on the measurement analysis of the two models.

First hypothesis: A statistically significant positive relationship at the level of $\alpha \geq 0.05$ exists between net investment cash flow and the decision to invest in companies in the industrial sector listed in the ASE.

Table 2 shows that the measurement estimation of the relationship between the change in net net investment cash flow and the change in investor's decision is negative, in which the estimated coefficient of the net net investment cash flow is $-2.26 \mathrm{E}-09$. The investments are negative in most of the years during the study period, which means that funds are not fully utilized in new cash-generating investments. This situation can adversely affect investors' decisions, especially in the industrial sector, which relies heavily on cash flows from cash-generating investment activities.

According to the t-test, this result is statistically significant at $1 \%$. The confidence level for this variable is $99 \%$; thus, this hypothesis is rejected. Moreover, a statistically significant positive relationship at the level of $\alpha \geq 0.05$ exists between net investment cash flow and decisions to invest in companies in the industrial sector listed in the ASE.

Second hypothesis: A statistically significant positive relationship at the level of $\alpha \geq 0.05$ is observed between net operational cash flow and the decision to invest in companies in the industrial sector listed in the ASE.

Table 1 shows that the measurement estimation of the model between the change in the net 0peration cash flow and the effect on investors' decisions is negative. This finding is because investors do not care about net operation cash flow generated by operations when making investment decisions because large operational inflows include taxes, interests, and consumption. Consequently, large operational inflows also include large costs that do not reflect profits that promote investors' decisions; thus, investors are not interested in investing in industrial companies.

Third hypothesis: A statistically significant positive relationship at the level of $\alpha \geq 0.05$ exists between net financing cash flow and decisions to invest in companies in the industrial sector listed in the ASE.

Table 2 shows that the measurement estimation of the relationship between the change in net financing cash flow and the change in investors' decisions is positive, in which the estimated coefficient of the net financing cash flow is 1.21E-09. This finding means that the relationship between the effect of the change in net financing cash flow and the change in investors' decisions is positive because companies in the industrial sector distribute large amounts to shareholders. This distribution leads to a high share price in the market, thereby reflecting the efficiency of management in the sector to obtain profits. Profits affect investors' decisions to invest in this sector because investors consider distributions that can be obtained from investments.

According to the t-test, this result is statistically significant at $5 \%$. The confidence level for this variable is $95 \%$; thus, this hypothesis is accepted. Moreover, a statistically positive significant relationship at the level of $\alpha \geq 0.05$ exists between financing cash flow and investors' decisions to invest in companies the industrial sector listed in the ASE.

Fourth hypothesis: A statistically significant positive relationship at the level of $\alpha \geq 0.05$ is observed between net investment cash flow and the decision to invest in companies in the service sector listed in the ASE.

Table 6 shows that the measurement estimation of the relationship between the change in net investment cash flow and the change in the investors' decisions is positive, in which the estimated coefficient of the net net investment cash flow is $3.11 \mathrm{E}-09$. This finding means that the relationship between the effect of the change in net 
investment cash flow and the change in investors' decisions is positive in this sector. The reason for this finding may be because the service sector is interested in acquiring assets, machinery and equipment, and modern technology owing to the large competition between the two sectors as well as growth, expansion, and development. Such factors promote investors' decisions, especially in this sector, which depends on the provision of fast and accurate services appropriate to the needs of the large investment spent on the competition between these sectors in Jordan.

According to the t-test, this result is statistically significant at $1 \%$. The confidence level for this variable is $99 \%$; thus, this hypothesis is accepted. Moreover, a statistically significant positive relationship at the level of $\alpha \geq 0.05$ is observed between net investment cash flow and the decision of investors to invest in companies in the service sector listed in the ASE.

Fifth hypothesis: A statistically significant positive relationship at the level of $\alpha \geq 0.05$ exists between net operational cash flow and investors' decisions on companies in the services sector listed in the ASE.

Table 6 demonstrates that the measurement estimation of the relationship between the change in operational cash flow and the change in investors' decision is positive, in which the estimated coefficient of the net investment cash flow is $1.78 \mathrm{E}-09$. This finding means that the relationship between the effect of the change in operational cash flow and the change in investors' decisions owing to net operation cash flows, including taxes, interests, and depreciation, is positive. The large amount of operation cash flows reflects huge taxes that negatively affect investment decisions because the service sector in Jordan imposes high tax rates.

According to the t-test, this result is statistically significant at $1 \%$. The confidence level for this variable is $99 \%$; thus, this hypothesis is accepted. Moreover, a statistically significant positive relationship at the level of $\alpha \geq 0.05$ exists between operational cash flow and the decision of investors to invest in companies in the service sector listed in the ASE.

Sixth hypothesis: A statistically significant positive relationship at the level of $\alpha \geq 0.05$ is observed between financing cash flow and the decision to invest in companies in the service sector listed in the ASE.

Table 5 shows that the measurement estimate of the model between the change in the net financing cash flow and the change in investors' decisions is negative. This finding is because investors do not consider the net financing cash flow generated by the operations of service companies when making investment decisions. This situation may rely on the needs of service companies embodied in cash flows from purchasing modern assets such as technology and innovation. Such assets distinguish them from other service companies such as telecommunications, hotels, and restaurants, which are interested in service innovations, such as machines and modern equipment that provide quality services.

\section{Results}

The review of the measurements, particularly the hypotheses, demonstrates that the net cash flows of the service sector positively affect investors' decisions. The reason is that companies in this sector acquire rather than sell new fixed assets. Consequently, companies can expand the production of quality innovative services, which in turn can promote investors' decisions in these companies. The net 0peration cash flow in the service sector adversely affects investors' decisions because net operation inflows include taxes, interests, and depreciation. Furthermore, the increase in operation cash flow reflects the high costs in the service sector, which has a negative impact on investment decisions in terms of net investment cash flow for the industry. This negativity may rely on the negativity of the net investment cash flow in this sector during most of the years in the study period. Accordingly, this sector relies on net investment cash flow for profits. This reliance can impact the net financing cash flow of the industry sector while affecting investment decisions positively. However, cash outflows from the sector are greater than the inflows into the sector because companies in the industrial sector distribute large shares to shareholders, which increase the share price in the market. This situation reflects the efficiency of management in the sector to obtain profits, which in turn motivate investors' decisions to invest in this sector. Investors consider distributions obtained from investments; however, the net Operation cash flow in the industrial sector has no effect on investors' decisions. This finding is attributed to investors' lack of interest in net operation inflows because operation cash flows include taxes, interests, and depreciation. Therefore, 0peration cash flow includes considerable costs that do not reflect profits that promote investors' decisions when no further impact for the net cash flows of the sector exists. The interest of companies to invest net cash flows to expand and express their creativity to distinguish themselves from other service companies, such as telecommunications, hotels, and restaurants, which are interested in service innovations such as modern machines and equipment to provide quality services, should be noted.

\section{Recommendations}

The study recommends the following based on the findings:

1. Net cash flows, namely, investment, operation, and financing, should be given attention as well as the reasons for their decline and increase through the disclosure of financial statements. 
2. Attention should be given to cash distributions by companies and their importance in promoting investment decisions.

3. Attention should be given to net investment cash flow, especially for obtaining hard assets, which reflects expansion and growth and increases investors' decisions.

4. Investors should pay attention to net operation cash flows, especially in the industrial sector, because operational activities are greater in the industrial sector than in the service sector.
5. Interest in modern financing tools such as murabaha and abstaining from using traditional instruments through loans should be encouraged because the first purchase of machinery (investment) directly positively affects investors' decisions and the second (commitment) adversely affects investors' decisions.

6. Openness is needed in companies in the Arab and global markets that deal with modern financial instruments such as the Islamic sukuk for investment financing rather than depending on the local market, which deals with traditional tools.

\section{Appendices}

Appendix 1 Data of Study Variables during the Study Period (2001-2017|)

\begin{tabular}{|c|c|c|c|c|c|c|c|c|}
\hline years & $\begin{array}{l}\text { investor decision in } \\
\text { the industry Sector } \\
\text { index (DMI)* }\end{array}$ & $\begin{array}{l}\text { the value of } \\
\text { net cash } \\
\text { flows } \\
\text { investment } \\
\text { in the } \\
\text { industry } \\
\text { during the } \\
\text { years of } \\
\text { study } \\
\text { (NCFII) }\end{array}$ & $\begin{array}{l}\text { the value } \\
\text { of cash } \\
\text { flows } \\
\text { 0peration } \\
\text { in the } \\
\text { industry } \\
\text { during the } \\
\text { years of } \\
\text { study } \\
\text { (NCFOI) }\end{array}$ & $\begin{array}{l}\text { The value } \\
\text { of net cash } \\
\text { flows } \\
\text { financing } \\
\text { in the } \\
\text { industry } \\
\text { during the } \\
\text { years of } \\
\text { study } \\
\text { (NCFFI) }\end{array}$ & $\begin{array}{l}\text { investor decision in } \\
\text { the service sector } \\
\text { index (DMS) }\end{array}$ & $\begin{array}{l}\text { the value of } \\
\text { net cash } \\
\text { flows } \\
\text { investment } \\
\text { in the } \\
\text { service } \\
\text { sector } \\
\text { during the } \\
\text { years of } \\
\text { study } \\
\text { (NCFIS)** }\end{array}$ & $\begin{array}{l}\text { The value } \\
\text { of cash } \\
\text { flows } \\
\text { 0peration } \\
\text { in the } \\
\text { service } \\
\text { sector } \\
\text { during the } \\
\text { years of } \\
\text { study. } \\
\text { (NCFOS) }\end{array}$ & $\begin{array}{l}\text { the value } \\
\text { of net cash } \\
\text { flows } \\
\text { financing } \\
\text { in the } \\
\text { service } \\
\text { sector } \\
\text { during the } \\
\text { years of } \\
\text { study } \\
\text { (NCFFS) }\end{array}$ \\
\hline 2001 & 0.1552837622286934 & 134396638 & 230599186 & 166137213 & 0.07145481415264794 & -208918366 & 218465093 & -28675687 \\
\hline 2002 & 0.243211571737972 & 90879948 & 210294713 & 145826382 & 0.09083667430875046 & -177532633 & 221474092 & -87075630 \\
\hline 2003 & 0.3571361849911978 & 99178896 & 283834375 & 214482316 & 0.2631263561681994 & -141004775 & 301696164 & -70390013 \\
\hline 2004 & 0.6477302808949853 & 94371167 & 314656081 & 223532627 & 0.4084022608008449 & -252750509 & 345450548 & -54922718 \\
\hline 2005 & 0.6915469664585654 & -162804624 & 146788082 & 71897035 & 0.3088155721849471 & -424756526 & 268606731 & 333233865 \\
\hline 2006 & 1.017089612148787 & -212585285 & 183997979 & -76521935 & 0.2771643985 & -311254826 & 378747809 & 7057780 \\
\hline 2007 & 1.102300428263404 & -101134994 & 221644041 & -89710961 & 0.4474397727320168 & -317410744 & 376044899 & 15973796 \\
\hline 2008 & 1.544369602956155 & -398336195 & 508171001 & 84075524 & 0.8817415273 & -342736576 & 373314571 & -70078221 \\
\hline 2009 & 0.9116539477686715 & -252123327 & 440465468 & -207859336 & 0.8891366299 & -439355073 & 528753716 & -84929835 \\
\hline 2010 & 0.5124178748359145 & -213617911 & 358143106 & -195237978 & 3.109633043627646 & -236291891 & 121337455 & 76456033 \\
\hline 2011 & 0.4164183859212317 & -185777235 & 573246519 & -179832755 & 0.4518113549179879 & -203722084 & 94703534 & 72530268 \\
\hline 2012 & 0.2217796372448875 & -95824842 & 332848569 & -333972467 & 0.2799391938937941 & -242132832 & 173078406 & 77012101 \\
\hline 2013 & 0.341851751176222 & -100356476 & 278443674 & -241685944 & 0.2686102210890061 & -185021025 & 102200787 & 104075273 \\
\hline 2014 & 0.3421608372683081 & -120565189 & 377159630 & -260094194 & 0.2634449517295295 & -252131798 & 370244442 & -277585938 \\
\hline 2015 & 0.3953191021997256 & -211866793 & 366121794 & -168815585 & 0.3918747209768807 & 561948372 & 1924529854 & 917188483 \\
\hline 2016 & 0.3716405220400794 & -84712733 & 124311493 & -136043574 & 0.2745956460740823 & 571200191 & 1886215033 & 65158484 \\
\hline 2017 & 0.4040763596125494 & -244268202 & 233311294 & -68736712 & 2.565191363336914 & 312680046 & 260382270 & 110024355 \\
\hline
\end{tabular}

Source: Amman stock exchange, www.ase.com.jo/ar/Cumulative Data Industrial Sector.xls and Cumulative Data service Sector.xls $(\mathrm{DMI})^{*}$ : investor decision in the industry Sector index calculated by the researcher $(\mathrm{DMS})^{* *}$ Investor decision in the service sector index calculated by the researcher 


\section{Appendix (2)}

\begin{tabular}{|c|c|c|c|c|}
\hline & & \multicolumn{3}{|c|}{ Dependent Variable: DMI } \\
\hline & & \multicolumn{3}{|c|}{ Method: Least Squares } \\
\hline & & \multicolumn{3}{|c|}{ Date: $04 / 14 / 19$ Time: $13: 42$} \\
\hline & & \multicolumn{3}{|c|}{ Sample: 117} \\
\hline & & \multicolumn{3}{|c|}{ Included observations: 17} \\
\hline Prob. & t-Statistic & Std. Error & Coefficient & Variable \\
\hline 0.0013 & -4.076938 & $5.55 \mathrm{E}-10$ & $-2.26 \mathrm{E}-09$ & NCFII \\
\hline 0.9941 & -0.007520 & $5.91 \mathrm{E}-10$ & $-4.44 \mathrm{E}-12$ & NCFOI \\
\hline 0.0146 & 2.816648 & $4.31 \mathrm{E}-10$ & $1.21 \mathrm{E}-09$ & NCFFI \\
\hline 0.0482 & 2.180079 & 0.176149 & 0.384019 & $\mathrm{C}$ \\
\hline 0.569176 & \multicolumn{2}{|c|}{ Mean dependent var } & 0.598950 & R-squared \\
\hline 0.374480 & \multicolumn{2}{|c|}{ S.D. dependent var } & 0.506400 & Adjusted R-squared \\
\hline 0.369739 & \multicolumn{2}{|c|}{ Akaike info criterion } & 0.263097 & S.E. of regression \\
\hline 0.565789 & \multicolumn{2}{|c|}{ Schwarz criterion } & 0.899862 & Sum squared resid \\
\hline 0.389226 & \multicolumn{2}{|c|}{ Hannan-Quinn criter. } & 0.857222 & Log likelihood \\
\hline \multirow[t]{7}{*}{1.236559} & \multicolumn{2}{|c|}{ Durbin-Watson stat } & 6.471631 & F-statistic \\
\hline & & & 0.006465 & Prob(F-statistic) \\
\hline & & \multicolumn{3}{|c|}{ Dependent Variable: DMI } \\
\hline & & \multicolumn{3}{|c|}{ Method: Least Squares } \\
\hline & & \multicolumn{3}{|c|}{ Date: $04 / 14 / 19$ Time: $13: 46$} \\
\hline & & \multicolumn{3}{|c|}{ Sample: 117} \\
\hline & & \multicolumn{3}{|c|}{ Included observations: 17} \\
\hline Prob. & t-Statistic & Std. Error & Coefficient & Variable \\
\hline 0.0005 & -4.516203 & $5.01 \mathrm{E}-10$ & $-2.26 \mathrm{E}-09$ & NCFII \\
\hline 0.0110 & 2.929707 & $4.14 \mathrm{E}-10$ & $1.21 \mathrm{E}-09$ & NCFFI \\
\hline 0.0003 & 4.835974 & 0.079166 & 0.382847 & $\mathrm{C}$ \\
\hline 0.569176 & \multicolumn{2}{|c|}{ Mean dependent var } & 0.598948 & R-squared \\
\hline 0.374480 & \multicolumn{2}{|c|}{ S.D. dependent var } & 0.541655 & Adjusted R-squared \\
\hline 0.252096 & \multicolumn{2}{|c|}{ Akaike info criterion } & 0.253527 & S.E. of regression \\
\hline 0.399134 & \multicolumn{2}{|c|}{ Schwarz criterion } & 0.899866 & Sum squared resid \\
\hline 0.266712 & \multicolumn{2}{|c|}{ Hannan-Quinn criter. } & 0.857185 & Log likelihood \\
\hline
\end{tabular}

Source: E- views program based on appendix (1).

\section{Appendix (3)}

\begin{tabular}{|c|c|c|c|}
\hline \multicolumn{3}{|c|}{ Breusch-Godfrey Serial Correlation LM Test: } \\
\hline 0.1251 & Prob. F(1,13) & 2.686905 & F-statistic \\
\hline 0.0879 & Prob. Chi-Square(1) & 2.911816 & Obs*R-squared \\
\hline
\end{tabular}

Lag (2)

\begin{tabular}{|c|c|c|c|}
\hline \multicolumn{3}{|c|}{ Breusch-Godfrey Serial Correlation LM Test: } \\
\hline 0.2197 & Prob. F(2,12) & 1.724324 & F-statistic \\
\hline 0.1499 & Prob. Chi-Square(2) & 3.794960 & Obs*R-squared \\
\hline
\end{tabular}

Source: E- views program based on appendix (1).

\section{Appendix (4)}

\begin{tabular}{|c|c|c|c|}
\hline \multicolumn{5}{|c|}{ Heteroskedasticity Test: ARCH } \\
\hline 0.9375 & Prob. F(1,14) & 0.006376 & F-statistic \\
\hline 0.9320 & Prob. Chi-Square(1) & \multicolumn{2}{c|}{0.007284} \\
\hline \multicolumn{4}{|c|}{ Heteroskedasticity Test: ARCH } \\
\hline 0.4040 & Prob. F(2,12) & 0.978453 & \multicolumn{2}{c|}{ F-statistic } \\
\hline 0.3494 & Prob. Chi-Square(2) & 2.103159 & Obs*R-squared \\
\hline
\end{tabular}

Source: E- views program based on appendix (1). 


\section{Appendix (5)}

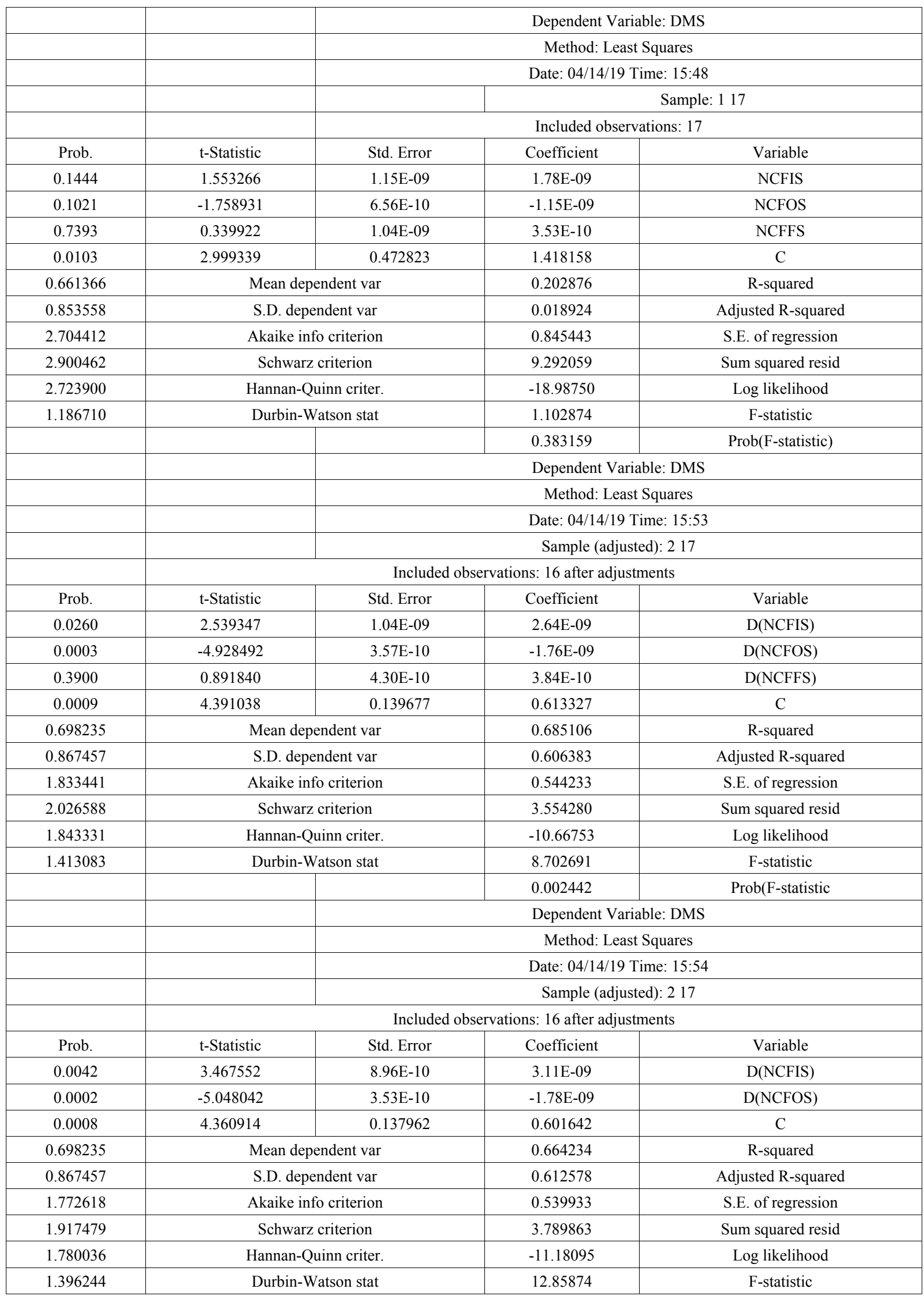

Source: E- views program based on appendix (1). 


\section{Appendix (6)}

\begin{tabular}{|c|c|c|c|}
\hline & \multicolumn{2}{|c|}{ Breusch-Godfrey Serial Correlation LM Test: } \\
\hline 0.3442 & Prob. F(1,12) & 0.969657 & F-statistic \\
\hline 0.2741 & Prob. Chi-Square(1) & 1.196216 & Obs*R-squared \\
\hline
\end{tabular}

\begin{tabular}{|c|c|c|c|}
\hline & \multicolumn{3}{|c|}{ Breusch-Godfrey Serial Correlation LM Test: } \\
\hline 0.4552 & Prob. F(2,11) & 0.846006 & F-statistic \\
\hline 0.3442 & Prob. Chi-Square(2) & 2.133011 & Obs*R-squared \\
\hline
\end{tabular}

Source: E- views program based on appendix (1)

\section{Appendix (7)}

\begin{tabular}{|c|c|c|c|}
\hline & & \multicolumn{2}{|c|}{ Heteroskedasticity Test: ARCH } \\
\hline 0.3794 & Prob. F(1,13) & 0.828065 & F-statistic \\
\hline 0.3433 & Prob. Chi-Square(1) & 0.898244 & Obs*R-squared \\
\hline & & \multicolumn{3}{|c|}{ Heteroskedasticity Test: ARCH } \\
\hline 0.3372 & Prob. F(2,11) & 1.201950 & F-statistic \\
\hline 0.2850 & Prob. Chi-Square(2) & 2.510807 & Obs*R-squared \\
\hline
\end{tabular}

Source: E- views program based on appendix (1).

\section{Appendix (8): The Descriptive Analysis}

\begin{tabular}{|c|c|c|c|c|c|c|c|c|}
\hline NCFFS & NCFOS & NCFIS & DMS & NCFFI & NCFOI & NCFII & DMI & \\
\hline 65003082 & $4.67 \mathrm{E}+08$ & $-1.35 \mathrm{E}+08$ & 0.661366 & -61915314 & $3.05 \mathrm{E}+08$ & $-1.16 \mathrm{E}+08$ & 0.569176 & Mean \\
\hline 15973796 & $3.02 \mathrm{E}+08$ & $-2.36 \mathrm{E}+08$ & 0.308816 & -89710961 & $2.84 \mathrm{E}+08$ & $-1.21 \mathrm{E}+08$ & 0.404076 & Median \\
\hline $9.17 \mathrm{E}+08$ & $1.92 \mathrm{E}+09$ & $5.71 \mathrm{E}+08$ & 3.109633 & $2.24 \mathrm{E}+08$ & $5.73 \mathrm{E}+08$ & $1.34 \mathrm{E}+08$ & 1.544370 & Maximum \\
\hline$-2.78 \mathrm{E}+08$ & 94703534 & $-4.39 \mathrm{E}+08$ & 0.071455 & $-3.34 \mathrm{E}+08$ & $1.24 \mathrm{E}+08$ & $-3.98 \mathrm{E}+08$ & 0.155284 & Minimum \\
\hline $2.54 \mathrm{E}+08$ & $5.53 \mathrm{E}+08$ & $3.10 \mathrm{E}+08$ & 0.853558 & $1.78 \mathrm{E}+08$ & $1.24 \mathrm{E}+08$ & $1.47 \mathrm{E}+08$ & 0.374480 & Std. Dev. \\
\hline 2.299433 & 2.176636 & 1.519579 & 2.149796 & 0.320440 & 0.584780 & 0.264602 & 1.238578 & Skewness \\
\hline 8.778081 & 6.111143 & 3.936962 & 6.188464 & 1.773497 & 2.667865 & 2.404735 & 3.733773 & Kurtosis \\
\hline 38.62952 & 20.27971 & 7.164352 & 20.29573 & 1.356484 & 1.047046 & 0.449365 & 4.727928 & Jarque-Bera \\
\hline 0.000000 & 0.000039 & 0.027815 & 0.000039 & 0.507508 & 0.592430 & 0.798770 & 0.094047 & Probability \\
\hline $1.11 \mathrm{E}+09$ & $7.95 \mathrm{E}+09$ & $-2.29 \mathrm{E}+09$ & 11.24322 & $-1.05 \mathrm{E}+09$ & $5.18 \mathrm{E}+09$ & $-1.97 \mathrm{E}+09$ & 9.675987 & Sum \\
\hline $1.03 \mathrm{E}+18$ & $4.90 \mathrm{E}+18$ & $1.53 \mathrm{E}+18$ & 11.65697 & $5.09 \mathrm{E}+17$ & $2.44 \mathrm{E}+17$ & $3.48 \mathrm{E}+17$ & 2.243765 & Sum Sq. Dev. \\
\hline 17 & 17 & 17 & 17 & 17 & 17 & 17 & 17 & Observations \\
\hline
\end{tabular}

Source: E- views program based on appendix (1). 


\section{REFERENCES}

[1] Andrew C. Call,(2007), The Implications of Cash Flow Forecasts for Investors' Pricing and Managers' Reporting of Earnings, University of Washington,

[2] Abdul Nafea Al Zararee and Abdulrahman Al-Azzawi (2014)., The Impact of Free Cash Flow on Market Value of Firm, Global Review of Accounting and Finance Vol. 5. No. 2. Pp. $56-6$

[3] Arun Upneja and Amit Sharma,(2009) Relationship between Changes in Cash Flow and Investments in Publicy Traded Restaurant Firms in the United States mFIU Review Vol. 27 No. 3, This article is available in Hospitality Review: http://digitalcommons.fiu.edu/hospital ityreview/vol27/iss $2 / 4$

[4] Asma Khan, Ahmad Kaleem and Mian Sajid Nazir, (2012)), Impact of Financial Leverage on Agency cost of Free Cash Flow: Evidencefrom the Manufacturing sector of Pakistan, Journal of Basic and Applied Scientific Research, J. Basic. Appl. Sci. Res., 2(7)6694-6700,

[5] Florentina- Simona, (2010), study on the importance of cash flow analysis based on rates in the financial decision-making process, Faculty of Economic and Business Administration University of Craiova .link: https://EconPapers.repec.org/RePEc:aio:rteyej:v:1:y:2010:i :15s:p:7-1.

[6] Jonathan Lewellen and Katharina Lewellen,( 2016), Investment and Cash Flow: New Evidence, Journal of financial and quantitative analysis,vol. 51, no. 4 , pp. 11351164

[7] Ibrahim Marwan Khanji1 \& Ahmad Zakaria Siam1(2015), The Effect of Cash Flow on Share Price of the Jordanian Commercial Banks Listed in Amman Stock Exchange, International Journal of Economics and Finance; Vol. 7, No. 5 .

[8] Malik Munir Abu Afifah \& Manal Slieman Abu Ghneim, Sensitivity of accounting disclosures (Applied study on Jordanian industrial joint stock companies) Ninth International Scientific Conference (The Arab Economic Situation and Future Options) https://www.asu.edu.jo/ar/E conomics/M_ghneem/Documents/1.pdf

[9] Muchiri Samuel Gitari. (2014), The Effect of cash flow on investments in fixed assetsfor companies listed at the Nairobi stock exchange , D61/73149/2009 , A research project submitted to the School of Business in partial fulfillment of the requirements for the award of a Master of Business Administration of the University of Nairobi. http://erepository.uonbi.ac.ke/bitstream/handle/11295/7576 8.

[10] Muhammad Liman And Aminatu Sani Mohammed.(2018), 0peration Cash Flow and Corporate Financial Performance of Listed Conglomerate Companies in Nigeria, IOSR Journal Of Humanities And Social Science (IOSR-JHSS), Volume 23, Issue 2, PP 01-11

[11] Musa Inuwa Fodio \& Ruth Ifeanyi Onah. (2013)Impact of Cash flow on Investment levels in quoted Nigerian
Manufacturing Firms. Research Journal of Finance and Accounting Vol.4, No.12, ISSN 2222-1697(Paper) ,www. iiste.org ISSN 2222-2847 (Online

[12] Nobanee, H., Abraham, J. (2017) The Impact of Free Cash Flow, Equity Concentration and Agency Costs on Firm's Profitability. Investment Management and Financial Innovations. 14 (2) pp 19-26.

[13] Ola Melander Maria Sandstrom and Erik Schedvin. (2017), The effect of cash flow on investment: an empirical test of the balance sheet theory, Empir Econ vol. 53, issue 2, 695-716, 53:695-716 DOI 10.1007/s00181-016-1136-y.

[14] Stephen A. Ross, Randolph W. Westerfield \& Bradford D. Jordan. (2010), Fundamentals of corporate finance, ninth edition, Mc Graw-Hill Irwin, New York. PP31-39http://w ww.aep.neu.edu.vn/FileManager/ThuVien/166085925-Ros s-Westerfield-Jordan-Fundamentals-of-Corporate-Finance9th-Ed-20101.pdf

[15] Syed Mohammad Khaled Rahman, Md \& Tahidur Rahman. (2017),Impact of Financial Leverage on Cash Flow Ratio: A Comparative Study Between Companies Listed on DSE, Journal of Finance and Accounting; 5(5): 177-184 http://www.sciencepublishinggroup.com $/ \mathrm{j} / \mathrm{jfa}$

[16] Zayol Patrick. Agaregh Tavershima \& Eneji Bartholomew Eje. (2017), Effect of Financial Information on Investment Decision Making By Shareholders of Banks in Nigeria, IOSR Journal of Economics and Finance (IOSR-JEF), e-ISSN: 2321-5933, p-ISSN: 2321-5925.Volume 8, Issue 3 Ver. III , PP 20-31 